|STVÁN KOLLA| ${ }^{1}$

\title{
IF CASTLES AND STATUES COULD SPEAK TO US. THE CHANGING FREEDOM OF HISTORICAL INTERPRETATION IN THE CASE OF SLOVAKIA
}

\begin{abstract}
Beside official "policy of remembrance", run primarily by state representatives or public institutions, and embodied in national holidays, monuments or in history textbooks, democratic societies offer the possibility to create a "culture of remembrance" by local actors within the public sphere. These local actors consist of NGOs, civic initiatives, local governments or even of the business sphere, the latter including so-called heritage industry actors (like historical hotels or private museums). As a result, the interpretation of historical narratives tends to become multi-faceted, interactive and inclusive, but the risk has also emerged that historical narratives can be fluid and banal as well. The present essay attempts to highlight how these bottom-up historical interpretations launched by local actors coloured the culture of remembrance in Slovakia, in a country where national history had been a servant of nation-building struggles practically throughout the whole $20^{\text {th }}$ century. As many initiatives for renovating fortresses, erecting statues, organising historical events or launching historical hotels elucidate it, non-state actors have become active and immanent change-makers of the policy of remembrance in Slovakia, having a sometimes intentional, sometimes unintentional effect on broadening the freedom of historical interpretation in the country.
\end{abstract}

Key words: heritage industry, heritage interpretation, culture of remembrance, transnationalisation of memory, Slovakia

Buried under the heritage was the title given to an interesting essay highlighting the alleged passivity of the Monuments Board in Slovakia, in a monograph issued by the Institute of Cultural Policy (Moravčíková, 2017).

${ }^{1}$ Asst. Prof.; Corvinus University Budapest; e-mail: istvankollai@gmail.com. 
One of the leaders of this think-tank, Magdaléna Vásáryová, a former ambassador of Slovakia to Poland, also refers to this slogan in the foreword of the aforementioned monograph: "one out of three [villages in Slovakia has] an abandoned mansion, castle, or at least a manor house, thanks to the long-term hostile attitude towards our nobility" (Vásáryová, 2017, p. 9). According to this pessimistic conclusion, "hostility" is the word which may describe the general attitude of Slovak national consciousness towards mansions, castles, manor houses. However, has this behaviour been changing for decades, especially those decades since the fall of communism? The present essay addresses this complex problem, namely how the attitude of Slovak historical consciousness towards this - inherited multi-ethnic - heritage has been changing throughout regimes and decades. A special focus will be placed on the recent decades after the fall of communism by posing the question: can we experience a plurality or freedom of historical interpretations in Slovakia rooted in the newly born democracy, and providing space for non-hostile behaviour towards its multi-ethnic heritage? ${ }^{2}$

\section{HERITAGE PROTECTION IN SLOVAKIA - CHANGES WITHOUT DEVELOPMENT?}

In order to answer this question, one needs to outline the main milestones of heritage protection and management in Slovakia, from the birth of Slovakia as an official territorial unit (first as a part of Czechoslovakia). After the disintegration of the Austro-Hungarian empire, the strong sense of resentment which went along with the building a new, modern and Slavic statehood tended to consider the heritage of old monarchies to be a kind of barrier in the face of this struggle. Communist Czechoslovakia inherited this attitude from the so-called interwar republic, coupled with the "social engineering" of Marxists, trying to utterly reinvent and replan public community spaces. This does not mean that heritage protection was not institutionalised by these regimes: a Government Committee (Vládny komisariát) was established in 1919 for heritage protection, led by Jan Hofmann, which was transformed into a permanent institute called the State

\footnotetext{
2 The present essay was completed thanks to the National Scholarship Programme of the Slovak Republic for the academic year 2017/2018, funded by the Ministry of Education, Science, Research and Sport of the Slovak Republic.
} 
Institute for Heritage Protection (Státny referát na ochranu pamiatok). However, regardless of institutions, heritage protection in Czechoslovakia had to face not just the reluctance of the Czechoslovak elite, but this antiheritage climate of Czechoslovak modernism was also fuelled by a kind of sense of practicality. A spectacular example for this case is when the State Institute for Heritage Protection initiated a public debate, even an official contest awarding prizes, among experts around the dilemma concerning how to open up historical spaces in a better way for people in Bratislava to move between the Old Town and its surroundings. Several submitted plans incorporated the demolition of old buildings or maintaining just their facades, and even "on the place of these objects, which are today under heritage protection, there were plans to erect new buildings" (Porubská, 2013, p. 37). Jan Hofmann had to conclude that the underlying principle of heritage protection was not favoured by the modern city-planning of those days: both independent plans and regulations of local governmental bodies intended to demolish protected houses in the Old Town. Eventually, the political changes in 1938 stopped these drastic plans and "they did not come to the forefront in this form anymore" (ibid.).

The protection of historical urban centres was formed and improved gradually during the $20^{\text {th }}$ century, not just in Slovakia but worldwide. In 1933, the highly recognised "Athens Charter" was adopted at the International Congress of Modern Architecture, tackling the question of cultural heritage, among other things. After the Second World War, the international communication of architects and heritage experts went further, adopting new charters while the Socialist Bloc was also active in this discourse, launching its own international platform called the Permanent Working Group of Socialist Countries for Renovating Historical and Cultural Heritage and Museum Values. Even a new law (Act 27/1987) was passed regarding the protection of historical settlements of Slovakia (Husovská, 2013). However, despite all these efforts, today's experts have reached the bitter conclusion that the era of communism meant the severe and permanent deterioration of historical urban centres. The secret of this contradiction must lie in the fact that these Old Towns were born and developed due to the effect of civic freedom, free markets and self-government, and in the absence of these circumstances, international committees proved to be utterly inadequate for revitalising urban heritage.

As decades passed following the birth of Czechoslovakia, it clearly turned out that the country could not handle the heritage on its territory 
which was not in tune with its official narrative, and rooted in the nobility, capitalism, as well as the activities of non-Slavic ethnic groups. However, Slovakia was not able to develop a stable attitude even towards its rural ("ludové") heritage. Although the first protected areas (reserves) of rural architecture were declared in the 1970s - and despite the current popularity of some of these sites like Cicmany - the tendency towards protection cannot be regarded as being unambiguously strengthened. According to experts, the number of "protected settlements" in this category has declined by $40 \%$ in recent decades (Baroková \& Zvarik, 2013). ${ }^{3}$

The fall of communism may be regarded a new milestone: ideological limitations ceased to exist (1989); national independence created room and responsibility for Slovakia's own historical interpretations (1993); and, finally, a democracy was born providing space for non-state activism (1998). However, national independence triggered attempts at nationbuilding, with the image of the country enduring a serious downturn between 1994 and 1998, until, finally, the time could come when historical interpretations were open to being built and raised up by the "people themselves". An interesting question is whether heritage assets on the territory of Slovakia, full of non-Slovak traces and stories, are able to generate multi-ethnic narratives of history. The hypothesis of this research project is that these tendencies do exist.

Before picking some examples (case studies), some data should be employed to confirm the dominant existence of heritage sites with ethnically non-Slovak and non-peasant roots. According to the existing law on heritage protection, there are two categories of larger heritage sites in Slovakia, namely heritage reserves and heritage zones. The first category was created during the communist era, while the second category came into use after the change of regime. Both reserves and zones have subcategories, such as "urban", "rural", and "technical" reserves, and "urban", "rural", "special" and "regional" zones. When analysing the ratio of several subcategories, we can reach the clear conclusion that urban sites are in a dominant position among larger heritage areas: 17 out of a total of 28 heritage reserves are historical urban centres, while this ratio is 52 to 83 in the case of heritage zones (Škulavík, 2013). When analysing the 17 urban heritage reserves further, their territorial locations show the following pattern:

\footnotetext{
${ }^{3}$ The authors call for increasing this number once again.
} 
- Five of them are historical old towns of traditional regional centres (Trnava, Nitra, Trencin, Zilina, Kosice).

- Two of them are in the catchment area ("vonzáskörzet") of old Pressburg (Bratislava Old Town and Svaty Jur).

- All three mining towns of Hauerland have been awarded this designation.

- The seven other urban heritage reserves - more than a third of the total number - can be found in Spis-Saris region.

- It is not too difficult to see, therefore, that the vast majority of the most important urban heritage areas represent the legacy of Slovakia's former German-speaking citizens.

In the following sections of this article, we will look through some examples of the bottom-up pattern of the pluralisation of memory, triggered by the freedom of historical interpretation. In the second section, the reinventing of castle areas will be presented with profit-based (market-led) and non-profit (NGO-led) examples. The third section tackles the different ways of conducting the patrimonialisation of urban spaces, primarily through scrutinising initiatives concerning erecting new statues: how efforts concerning the patrimonialisation of urban spaces by the new Slovak middle class have led to post-modern historical interpretations.

\section{REINVENTING RURAL SPACES IN SLOVAKIA}

In the following subchapter, some examples will be given concerning initiatives aimed not only at the renovation of castles, manors or other rural sites, but also at the reinvention of their narratives, their "historical message". Regarding castles, one may assume that these local narratives may differ from the traditional Slovak nation-building narratives which consider the atmosphere of these heritage sites as culturally distant from Slovaks.

Renovated castles, manors and villas may typically serve as hotels after their rebirth. These initiatives have their own association called Historic Hotels of Slovakia. As the part of the umbrella organisation of the European Heritage Hotels Association, many Slovak members have already received international awards, such as the Grandhotel Stary Smokovec which was ranked second in the "A story to tell" category. The association has altogether fifteen members from Slovakia (Members, n.d.). 
On investigating the stories of these castle hotels, an apparent aim of trying to mix the business interests with heritage protection and management becomes clear. The latter may be fuelled by the personal commitment of the owners, or, by the pure business interest of seeming "authentic", "original" and "worth discovering". One of the members of this association, for instance, is Château Gbelany, whose new Slovak owner has struggled to renovate the castle in its historic form. Having issued a call to collect old items once belonging to the castle but just securing a few little things, they even contacted the previous owners for this reason. This attempt was successful: "They gave us the coat of arms of Majláths" (Stuppacherová, 2016). The most recent event within the association is the joining of the Galicia Nueva Castle Hotel, which is a luxury hotel in Novohrad county and where extensive restoration work was conducted before its opening. In this work, led by the restorer Vladimír Plekanec, $400 \mathrm{~m}^{2}$ was examined, resulting in the renovation of portraits of the kings of Hungary, which may also be seen as part of guided tours. ${ }^{4}$

It is also worth dealing with the castle of Hermanovce in detail as it unveils a real grassroots initiative, engaging the previous owners of the historical building in question. Hermanovce is a settlement in the vicinity of Prešov in Saris county, where the Péchy family had a large mansion for centuries that was expanded with an English garden and other small buildings in the $19^{\text {th }}$ century. In the $20^{\text {th }}$ century, this castle had to go through the same brutal process as essentially every mansion in the historical region of Upper Hungary: at the end of the Second World War the castle was robbed, the building nationalised and the owners deported. This rapid destruction was followed by decades of decay, and the castle eventually became a dead stone mound (Tomičová, 2014). However, after the change of regime, Klara Szakall von Losoncz, a Swiss lady who was the granddaughter of the last owner of the castle visited the site. Her grandfather, the last head of this branch of Péchy family found himself in Russian captivity after the Second World War while his daughter was sent to a Czech labour camp. This young woman met a young man from the Szakall von Losoncz family there, a former owner of a spa in eastern Slovakia who worked in the local mine at that time. In the world of labour camps of the 1950s, a real distinguished unification was made between these two families in

\footnotetext{
${ }^{4}$ Press releases available at https://zamockyhotelgalicianueva.sk/press-room.
} 
the form of their newborn daughter, Klara Szakall von Losoncz. Although she spent most of her life in Switzerland, she maintained her ability to speak Czech from her childhood. In addition, the memory of the deceased half-commoner/half-noble microcosm of her ancestors was absorbed in Switzerland, since the family, forced into emigration, nurtured family memories. Eventually, this motivated Klara to request the ownership of the castle (according to the law of restitution), following which she renovated it, now in the form of a luxury hotel (Vavrová, 2015). It is worth viewing the pictures of the castle on the Internet: the taste and opulence that we see here are the result of a 15-year effort and obviously the result of a lot of money. Architectural and cultural tourism prizes have been awarded to this newly established hotel in Slovakia and abroad. The owner has tried to meet the strongest market trends - offering it as a wedding venue - while struggling to recall something about the deceased multi-lingual world. This interwar world was an unlikely combination of pre-modern multi-lingual aristocracy and modern social life with tennis courts and swimming pools, with relatives arriving from Budapest during the holiday season in a Tatra luxury car from Prague. Although a cosmopolitan microcosm had emerged here with cultural openness, it remained socially closed, in the middle of Czechoslovakian mass democracy, far from the reality of the vast majority of local people. As a kind of good practice, and as proof of the possibility to operate a mansion on a market-based mechanism, it may be a good prospect for similar heritage buildings seeking a better fortune (Szakall von Losoncz, 2017).

The above-mentioned initiatives are profit-based solutions, launched by private owners, having a business model, and aiming to make heritage profitable. However, NGOs, local communities and non-profit initiatives also tackle the question of heritage protection, adding a multi-ethnic narrative to these sites. One of the most successful NGOs in this field is the Black Holes (Čierne diery) Civic Association. They achieved one of their greatest successes with a non-profit-based analysis of industrial heritage. Although their original aim was to discover the traces of industrial life, as a side-line, the association is also actively engaged in composing or strengthening multi-ethnic narratives. Their activism was originally the most spectacular in Gemer, a southern county of Slovakia: "Gemer had become the iron county of Hungary, now this legacy of the Andrássy family had fallen into ruins" - they concluded (Čierne Diery, 2017). To bring these territories back 
from invisibility, and back to the mental map of Slovaks, they mapped and published the technical heritage of Slovak cities, used billboards to warn about the illegal destruction of heritage monuments, as well as urging the police and heritage institutions to deal with the situation. ${ }^{5}$

The Black Holes Civic Association is a good example of when non-profit behaviour meets professionalism. However, there is no evidence that either profit-based or non-profit initiatives will meet high-quality, professional criteria of heritage protection and historical interpretation. In other words, grassroots initiatives may pose a risk of addressing heritage in an enthusiastic, but amateur way. Nevertheless, if we investigate the "amateur activism" in the field of ruined castles and fortresses, we can see that these energetic local struggles can gradually involve official institutions or experts dealing with heritage protection. Therefore, as a general pattern, the gradual process of professionalisation can be shown in several NGO-led initiatives.

A good example of this is the castle of Sklabina. The visitor is attracted to the particular spirit of this place, as a small farm has developed at the base of the castle with pets, while a local civic organisation has established its own small museum here, exhibiting excavation finds. As a result, a miniecosystem was formed around the deserted fortress. A local guided tour was also launched here by the Donjon civic association, aimed towards the restoration of the whole castle, gathering historians and young urban professionals among its members who had fallen in love with the countryside. There are a few things in the museum that visitors do not expect in such a place: for example, a giant churn suitable for making cheese, and where fresh sheep's cheese may be bought and consumed. This cheese is not the end of the "cultural shocks" on offer: the guided tour is also full of surprising stories, constituting a difficult-to-understand narrative about the heroism of Slovak warriors. These confused histories had a major conclusion, however: here the Slovaks have always fought for the independence against "aliens". Although the values that had been uncovered from the earth served here as a chaotic, amateur nation-building narrative, as stated above, the institutionalisation of such grassroots initiatives can shift amateurism into professionalism. For instance, the president of the Donjon

\footnotetext{
${ }^{5}$ See more at http://ciernediery.sk/kto-sme/.
} 
civic association published a book about the castle, but together with a researcher (Eliáš \& Svateník, 2017). ${ }^{6}$

The very spectacular route of the above-mentioned luxurious castle hotels is still unique. Another village in the near, called Pečovská Nová Ves, which was named after the local landowner Péchy family, is not in such a fortuitous situation, however. Although the settlement has three castles and one mansion on the cultural heritage list, ${ }^{7}$ there is no clear idea concerning their utilisation. Just one mansion is in a renovated state, used by the local council (Program rozvoja, 2016). The development plan of the settlement just displays very general wishful thinking about the future of these objects, while the list of already-elaborated projects does not contain any special ideas for these castles. The desperate struggle of local governments to find investors may produce special solutions. Thus, in order to raise awareness towards the abandoned historic buildings in Pečovská Nová Ves, the deputy mayor Stanislav Karabinoš began to write a book about the village - this is also an example of "amateur enthusiasm", with the prospect of turning into professionalism (Viaceré kaštiele, 2016).

Another special solution was chosen in the case of the above-mentioned castle in Sklabina, namely local government begun to launch an advertising campaign to sell it. Thus the medieval fortress was placed on a real estate portal, as a strange example of how a ruin can become a marketable product, with exact measurements as calculated by real estate agents, as if it were an apartment or a holiday home. According to the advertisement, "the property" was built in the $13^{\text {th }}$ century, its condition "has deteriorated a lot" and has a floor area of 9,600 $\mathrm{m}^{2}$. It is accessible by car, and if somebody has a quarter of a million euros, they may call the real estate agent immediately. At the same time, the ruined castle is also impressive, with its pictures on the Internet worth looking at, along with the real estate agent's commercial advertisement for it. Indeed, there is also a commercial for Sklabina, aimed at trying to sell it.

These examples show the tendency concerning how lovers of the countryside, archaeologists, ancestor-seeking immigrants, hotel managers

${ }^{6}$ The question arises logically: Why do such reconstruction works not belong to museums and heritage agencies? This may be related to the confusing property regulations and disputes around property ownership.

${ }^{7}$ See more at http://www.pamiatky.sk/sk/page/evidencia-narodnych-kulturnychpamiatok-na-slovensku. 
and deputy mayors can involve themselves in the historical interpretations of rural heritage sites, having an intentional or unintentional side-effect on the plurality of narratives within Slovakia. In urban spaces, where the city creates a complex heritage site in itself, this process is based more strongly on local government.

\section{REINVENTING URBAN SPACES IN SLOVAKIA}

International literature generally acknowledges that local development may have a major impact on local identity, or at least a significant impact on it. Local community developments can not only improve the quality of life, but also increase the internal cohesion of a community and the prestige of belonging to it (geo-branding), which embodies narratives strengthening or building local memory (Graham, Ashworth \& Tunbridge, 2016). The main actors of local community development are local governments or NGOs that cooperate with them. If we look through the initiatives of the local authorities or civilians in Slovakia, many of these initiatives are trying to build locally understandable brands based on figures from the pre-modern period, primarily from among the rulers of the multi-ethnic Kingdom of Hungary. Thus, a bottom-up mechanism of the transnationalisation of memory can be distinguished, resulting in local historical interpretations with a multi-ethnic content (Tota \& Hagen, 2016).

In Bratislava, the process of the transnationalisation of memory is strongly linked to two rulers: Maria Theresa, and more recently king Matthias. Maria Theresa had already been placed in the forefront in the city's local memory in the $19^{\text {th }}$ century, as one of the developers of former Pressburg. Her ruling years are strongly linked to the historical fact that as a great many aristocratic families erected palaces in this city, close to the Viennese courtyard, cultural and economic life developed. The city honoured her in 1897 by unveiling a statue made in Carrara marble by János Fadrusz. The brutal fate of the statue symbolises the $20^{\text {th }}$ century history of Bratislava: in 1921, in a deep anti-Hungarian and anti-monarchical mood, Czechoslovak legionaries smashed the work of art into pieces (Mannová, 2015, p. 241).

Over the course of almost a hundred years since then, Pressburg, now Bratislava, has changed very much: the question of Slovak attitudes 
towards Hungarians and the question of state sovereignty, national emancipation - or their hysterical appearance - are not characteristic of the discourse of public life in the Slovakian capital. In the context of historical memory, the need for the self-representation of the middle class in Bratislava has come to the fore, utilising somehow the multi-ethnic past of this city, and also triggered by the necessity of "place marketing" for an increasing European prestige.

In these struggles, the well-known queen (and, in fact, empress) may be awarded an important role (Čobejová, 2017). Indeed, these are the motivations behind the initiatives of renovating the ruined sculpture of $\mathrm{Ma}$ ria Theresa. This motion has sparked off serious disputes and its reception was not clearly positive. Indeed, these anxieties are not so much related to the character of Maria Theresa but rather to the dilemma of art history, whether it is appropriate to set up a replica of an old statue in the third millennium instead of preparing a new work of art (Hilbertová, 2011). Eventually, the Bratislava Beautification Society temporarily set up a "replica of the replica" on the Danube riverbank in Bratislava, which was a plaster cast of Maria Theresa's equestrian sculpture. ${ }^{8}$ The Society is also about to erect a bronze replica in the near future.

Moreover, there are also some new royal sculptures beyond Bratislava: the Hungarian king from the Anjou dynasty, Louis the Great, was commemorated by a statue in Skalice in 2008, and his father (Charles Robert) was similarly recognised in Kremnica in 2011. Both of them had gained attention due to their deep influence on regional development in a historical perspective: the previous ruler was the founder of Skalice, and the latter awarded town privileges to Kremnica (1372, the declaration of "free royal town"). Interestingly enough, not only medieval figures have been commemorated by statues in the territory of Slovakia. In 1998, a memorial was erected concerning a medieval charter from the year 1111 which confirmed the privileges of Nitra Abbey, while Kosice chose the same way of remembrance with the unveiling of a statue of its coat of arms which had been awarded by Louis the Great in 1369 (Lacika, 2013).

This dispute will possibly grow broader in the future. For instance, the city administration of Banská Bystica initiated the commissioning of

\footnotetext{
${ }^{8}$ However, in fact, Maria Theresa had already been commemorated by a sculpture in Bratislava after the change of regime: in 1992, a small carving was set up in the garden of the archbishop's palace, which had been previously found in Nitra (Kollai, 2009).
} 
a statue of king Béla IV who was the ruler who awarded the settlement municipal rights in 1255. Even a call was launched to the public at large to encourage citizens to donate to the project, with city officials expecting contributions by the end of 2017 (Mesto Banská Bystrica, 2017).

Such an open step would not have been possible in the earlier incarnations of Slovakia, under the tight control of state-led memory policy of Czechoslovakism, communism or Meciarism. As a result of these rigorous and monolithic nation-building policies, the memory of monarchs and dynasties, especially of the Árpád dynasty (rulers of Hungary from 1000 to 1301) had faded away utterly, disappeared from the pages of history textbooks and from the mental map of Slovaks. Just some very hidden traces had been maintained, such as the coat of arms of Banská Bystrica or Presov, featuring the Árpáds' red and silver banners, referring indirectly to the founders (or a tiny street named after Béla IV in Zvolen, as a pale reminder of the king who developed the town). If the present call of Banská Bystrica had been successful, this would have been the first statue commemorating members of Árpád dynasty, initiated directly by Slovak authorities.

In the above examples, the initiators were local governments or NGOs closely related to them. Although, in most cases, they seem to be the actors launching multi-ethnic historical interpretations, market players may also appear among these actors, primarily through the heritage industry embodied in tourism and by real estate developments which need "place marketing" also. A very vivid example of the latter is the case when a new residential and office district was to be planned and built in Bratislava, and in which a new square will be formed by new buildings. This newlyborn square is to be named after king Matthias. While this proposal was made by Radoslav Števčík, Mayor of Bratislava Old Town, it is also supported by the Blumental Office real estate development company. They argue that king Matthias had a "close and positive relationship" with the city and had a serious impact on Bratislava's educational history by establishing a university named Academia Istropolitana. According to the mayor's statement, the name of the king Matthias (Námestie Mateja Korvína) is appropriate because the king has "done a lot for the city's development in art, culture and economy" (V Starom Meste, 2017). His "popularity" in Bratislava originates from the memory of the university he created here. As a modern brand, the memory of this university is currently being built further by a non-governmental organisation, Academia Istropolitana Nova, located on the elegant outskirts of the capital city, where cultural heritage, 
urban development and democratic education are organised, through offering conferences and developing e-learning materials. ${ }^{9}$

One may conclude that local government, market actors and NGOs are also active participants in the field of place branding, and all of them like to choose royal brands. From the point of view of their motivations, the rediscovery and reinventing of kings, queens, dukes and monarchs in such a form can be explained in that their characters symbolise power, success, and a patina of some kind of authentic Europeanism. ${ }^{10}$ The renaissance of rulers' popularity in this region seems to be related with the fact that local societies lack the centuries-old urban traditions of citizenry and the centuries-old capitalist traditions of family businesses and deeply rooted local firms. Indeed, in their absence, principally rulers or magnates can become symbols of heritage-based branding, both in public spaces, in private spaces and in business. Thus, the memory of pre-modern dynasties endures not just in dead bronze or stone statues, but also in their spirit which is rejuvenated, reinvented (or, moreover, overwritten in a post-modern style) by living organisms, by local actors such as real estate developers and civilians. In this way, the Slovak audience experiences a kind of "new pluralism" of historical interpretations, being sometimes in contradiction with each other, but colouring the earlier monolithic Slovak self-image, and symbolising that freedom of speech tackles history as well.

\section{BIBLIOGRAPHY}

Bammer, A. (1994). Displacements. Cultural Identities in Question. Bloomington-Indianapolis: Indiana University Press.

Baroková, D., \& Zvarik. E. (2013). Príspevok k urbanistickému vývoju a stavu zachovania historickej štruktúry a hodnôt architektúry v Nižnej Boci. Monument revue. 2, 28-31.

Čierne Diery. (2017). N Magazin. 6 [special edition].

Čobejová, E. (2017). Inšpirujúcejšia ako Sissi. Týždeň. 19. Retrieved from https://www.tyzden. sk/temy/39271/inspirujucejsia-ako-sissi/

Eliáš, M., \& Svateník, M. (2017). Hrad Sklabina a jeho páni. OZ Donjon.

Graham, B., Ashworth, G. J., \& Tunbridge, J. E. (2016). A Geography of Heritage: Power, Culture \& Economy. London: Routledge.

\footnotetext{
${ }^{9}$ See citations and more at www.ainova.sk.

${ }^{10}$ This phenomenon of commodification of the past has already been scrutinised by researchers of the heritage industry (Bammer, 1994, p. 111).
} 
Hilbertová, M. (2011, November 3). Mária Terézia sa zatial' nevzdáva. SME. Retrieved from https://bratislava.sme.sk/c/6124665/maria-terezia-sa-zatial-nevzdava.html

Husovská, L. (2013). Formovanie ochrany historického urbanizmu - pamiatkové rezervácie a pamiatkové zóny. Monument revue. 2, 2-9.

Kollai, I. (2009). A Capital on the Borderland. Traditional Multiculturalism in Contemporary Bratislava. Budapest: Terra Recognita Foundation.

Lacika, J. (2013). Pamätníky a pomníky. Bratislava: Dajama.

Mannová, E. (2015). Pomníková kultúra v Bratislave. Spomínanie - vizualizácia moci reprezentácia. Acta Historica Neosoliensia. 18, 236-257.

Members. (n.d.). Retrieved October 14, 2018, from https://www.historichotelsofslovakia.com/

Mesto Banská Bystrica. (2017). Dobrovol'ná verejná zbierka na sochu krála Bela IV. v Banskej Bystrici. Retrieved October 11, 2018, from https://bela.visitbanskabystrica.sk/

Moravčíková, H. (2017). Pochovaní pod pamiatkami, alebo ako pamiatkový úrad zaspal dobu. In Živá kultúra a pamiatky. Zborník príspevkov z konferencie "Pochovaní pod pamiatkami” (pp. 107-109). Bratislava: Via Cultura - Inštitút pre kultúrnu politiku.

Porubská, B. (2013). Regulácia Bratislavy v medzivojnovom období. Sútaž na reguláciu okolia Michalskej brány. Monument revue. 2, 32-37.

Program rozvoja obce Pečovská Nová Ves na roky 2015-2022. (2016). Pečovská Nová Ves: Obecný úrad.

Stuppacherová, B. (2016, July 28). Gbel'any: ako vytiahnut' kaštiel'z kaše. Pravda. Retrieved from https://zurnal.pravda.sk/reportaz/clanok/400254-gbelany-ako-vytiahnut-kastiel-z-kase/

Szakall von Losoncz, K. (2017, March). Es war einmal ein Schloss. Schöner Wohnen Spezial, pp. 136-142.

Škulavík, P. (2013). Pamiatkové územia ako súčast' pamiatkového fondu Slovenska. Monument revue. 2, 39-41.

Tomičová, S. (2014). Záchrana kultúrnej pamiatky s využitím poskytovania reštauračnoubytovacích služieb (Bachelor thesis, Vysoká škola hotelová v Prahe). Retrieved October 11, 2018, from https://is.vsh.cz/th/f3ba0/?so=nx

Tota, A. L., \& Hagen, T. (Eds.). (2016). Routledge International Handbook of Memory Studies. London: Routledge.

Vásáryová, M. (2017). Foreword. In Živá kultúra a pamiatky. Zborník príspevkov z konferencie „Pochovaní pod pamiatkami” (pp. 9-11). Bratislava: Via Cultura - Inštitút pre kultúrnu politiku.

Vavrová, T. (2015, September). Druhy domov. Forbes, pp. 53-56.

Viaceré kaštiele v Pečovskej Novej Vsi schátrali. (2016, October 15). Korzár. Retrieved from https://presov.korzar.sme.sk/c/20356215/viacere-kastiele-v-pecovskej-novej-vsi-schatrali. html

V Starom Meste chcú Námestie Mateja Korvína. (2017, February 8). SME. Retrieved from https://bratislava.sme.sk/c/20454493/v-starom-meste-chcu-namestie-mateja-korvina.html 